\title{
A new species of Characidium Reinhardt, 1867 (Characiformes: Crenuchidae) endemic to the Atlantic Forest in Paraná State, southern Brazil
}

\author{
Marcelo R. S. Melo ${ }^{1}$, Paulo A. Buckup ${ }^{2}$ and Osvaldo T. Oyakawa ${ }^{3}$
}

A new species of Characidium is described based on specimens obtained from the highland streams of the Serra do Mar, Atlantic Forest Biome, in Paraná State, Southern Brazil. The new species is possibly a member member of the C. lauroi group, which is diagnosed by having the isthmus unscaled, bars poorly marked, and spots on sides of body, and is composed by four additional species: $C$. japuhybense; $C$. lauroi; $C$. oiticicai; and $C$. schubarti. The new species differs from its congeners with naked isthmus, except $C$. helmeri, by having 15-18 principal caudal-fin rays; and 10-12 pectoral-fin rays; and from $C$. helmeri, by having a slender body, tip of pectoral fin not reaching origin of pelvic fin, tip of pelvic fin not reaching beyond anus, supraorbital present and well developed, and by lacking vertically elongated dashes on sides of body. The new species is known from tributaries of the rio Jordão, in the rio Iguaçu Basin, and rio Taquari, a tributary of the rio Ribeira de Iguape coastal drainage.

Uma nova espécie de Characidium é descrita com base em exemplares obtidos de riachos de altitude da Serra do Mar, no bioma Mata Atlântica, do Estado do Paraná, Sul do Brasil. A nova espécie é possivelmente um membro do grupo C. lauroi, que pode ser diagnosticado por possuir o istmo sem escamas, barras pouco marcadas e pontos nos lados do corpo, e é composto por quatro espécies adicionais: $C$. japuhybense; $C$. lauroi; $C$. oiticicai; e $C$. schubarti. A nova espécie difere de seus congêneres com istmo nú, exceto $C$. helmeri, por possuir 15-18 raios principais na nadadeira caudal, e 10-12 raios na nadadeira peitoral; e de $C$. helmeri, por possuir o corpo mais alongado, pela ponta da nadadeira peitoral não alcançar a nadadeira pélvica, pela ponta da nadadeira pélvica não alcançar o ânus, pelo supraorbital presente e bem desenvolvido, e pela ausência de manchas verticalmente alongadas na porção ventral do corpo. A nova espécie é conhecida de duas drenagens, nos tributários do rio Jordão, na bacia do rio Iguaçu, e no rio Taquari, um tributário da bacia costeira do rio Ribeira de Iguape.

Keywords: Characidium lauroi group, Mata Atlântica, Rio Iguaçu, Rio Ribeira de Iguape, South American Darters.

\section{Introduction}

Species of Characidium Reinhardt, 1867 are typical inhabitants of the small to medium-sized streams in the Neotropical Region, from eastern Panama to northern Argentina (Buckup, 1993b; Buckup, 1999). Characidium currently includes 66 valid species, including a new species described herein (Eschmeyer et al., 2016). Thirteen species are endemic to the streams of the Serra do Mar Ecorregion, in the Atlantic Forest Biome (sensu Scaramuzza et al., 2011): C. alipioi Travassos, 1955; C. grajahuense Travassos, 1944; C. interruptum Pellegrin,1909; C. japuhybense Travassos, 1949; C. lanei Travassos, 1967; C. lauroi Travassos, 1949; C. litorale Leitão \& Buckup, 2014; C. oiticicai Travassos, 1967; C. pterostictum Gomes, 1947; C. schubarti Travassos, 1955; C. timbuiense Travassos, 1946 and C. vidali Travassos, 1967 (Menezes et al., 2007; Leitão \& Buckup, 2014).
Herein we describe a new species of Characidium, only known from a few localities in Paraná State: the tributaries of rio Jordão, a tributary of the right bank of rio Iguaçu, rio Paraná-Basin; and the rio Capivari, in the southern part of the rio Ribeira de Iguape, a coastal drainage. The new species is hypothesized as a member of the C. lauroi group of species. The C. lauroi group is composed by four additional species, endemic to the clear water streams of the Serra do Mar between Paraná and Rio de Janeiro States: C. japuhybense Travassos, 1949, from the coastal drainages in São Paulo and Rio de Janeiro; C. lauroi Travassos, 1949, from the tributaries of the upper and middle rio Paraíba do Sul; C. oiticicai Travassos, 1967, from the upper rio Tietê and rio Ribeira de Iguape; and C. schubarti Travassos, 1955, from the headwaters of rio Paranapanema and rio Ribeira de Iguape (Travassos, 1949a, 1949b, 1955a, 1967; Bizerril \& Primo, 2001; Buckup \& Melo, 2002; Oyakawa et al., 2006).

\footnotetext{
${ }^{1}$ Departamento de Oceanografia Biológica, Instituto Oceanográfico, Universidade de São Paulo, Praça do Oceanográfico, 191, 05508-120 São Paulo, SP, Brazil. melomar@usp.br (corresponding author)

${ }^{2}$ Departamento de Vertebrados, Museu Nacional, Universidade Federal do Rio de Janeiro, Quinta da Boa Vista, 20940-040 Rio de Janeiro, RJ, Brazil. buckup@acd.ufrj.br

${ }^{3}$ Museu de Zoologia, Universidade de São Paulo, Av. Nazaré, 481, 04218-970 São Paulo, SP, Brazil. oyakawa@usp.br
} 


\section{Materials and Methods}

Morphometric and meristic data were obtained from the left side of specimens, under a binocular stereomicroscope, according to Buckup (1993a) and Melo \& Oyakawa (2015). Measurements were taken using a digital caliper to $0.1 \mathrm{~mm}$. Counts are listed in the text, followed by their frequencies in parentheses; an asterisk indicates the value for the holotype. Osteological characteristics were observed in cleared and stained specimens (cs), which were prepared according to Taylor \& Van Dyke (1985). Terminology for caudalfin elements follows Fujita (1990), the vertebral counts included the five anterior-most elements modified into the Weberian apparatus counted individually, but the urostyle was counted as a single element, and the supernumerary elements in dorsal and anal fins were counted only from cleared and stained individuals. Institutional abbreviations follow ASIH codes listed at http://asih.org/codons.pdf.

\section{Results}

\section{Characidium travassosi, new species}

urn:1sid:zoobank.org:act:8E9458F1-8580-473A-A518442015049 C 86

\section{Figs. 1 a-e and 3 a-c, Table 1}

Characidium sp. "iguaçu”. -Melo, 2001: 39-41, figures 5b, 12; table 6. Characidium sp. 2. -Baumgartner et al., 2012: 71.

Characidium sp. B. -Severi \& Cordeiro, 1994: 47-48.

Holotype. MZUSP 85940, 33.8 mm SL, Brazil, Paraná, Reserva do Iguaçu, rio das Torres, a small tributary of rio Jordão, rio Iguaçu basin, $38 \mathrm{~km}$ southeast of Pinhão, 254'28”S, 5159’01”W, 10 Jan 2001, C. R. Moreira.

Paratypes. All from Brazil, Paraná: MCP 22605, 11 (2 cs), 23.0-51.4 mm SL, Guarapuava, arroio [rio Pai João] tributary of rio Jordão, rio Iguaçu basin, at $\mathrm{Km} 386$ of road BR-373, towards the locality of Laranjeiras do Sul, between

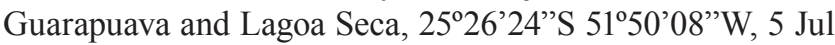
1998, C. A. S. Lucena et al. MCP 22606, 1, $44.1 \mathrm{~mm} \mathrm{SL}$, border between Candói and Guarapuava, rio Campo Real, tributary

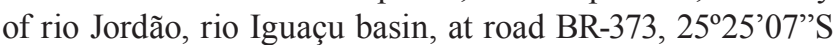
$51^{\circ} 46$ '55”W, 05 Jul 1998, C. A. S Lucena et al. MNRJ 36865, 11, 26,8-41,8 mm SL; and MNRJ 36866, 50, 18.9-27.8 mm, Garapuava, small stream tributary of rio Jordão, rio Iguaçu basin, at $\mathrm{Km} 383$ of road BR-373, 25⒉ $6^{\prime} 03^{\prime \prime} \mathrm{S} 51^{\circ} 48^{\prime} 34^{\prime \prime} \mathrm{W}$, 16 Oct 2009, C. E. Lopes et al. MNRJ 21542, 1, $36.1 \mathrm{~mm} \mathrm{SL}$, Pinhão, rio das Torres, small tributary rio Jordão, rio Iguaçu basin, 21 Oct 1991, W. B. Wosiacki \& A. C. Carrilo. MNRJ 21543, 2, 32.0-57.1 mm SL, collected with MNRJ 21542. MNRJ 40796, 1, 48.2 mm SL, Quatro Barras, rio Taquari, tributary of rio Capivari, rio Ribeira de Iguape basin, in front of Morada do Silêncio Chaminé da Serra da Ordem Rosa

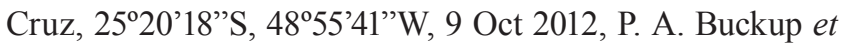
al., MHNCI 8601, 2, 25.4-46.6 mm SL, Pinhão, rio das Torres, a tributary of rio Jordão, rio Iguaçu basin, 21 Oct 1991, W. B. Wosiacki \& A. C. Carrilo. MZUSP 85938, 7 (1 cs), 29.7-33.8 $\mathrm{mm}$ SL, at the border between Pinhão and Reserva do Iguaçu, rio Quadrado, rio Iguaçu basin, $8 \mathrm{~km}$ west of Pinhão along the road PR-459, 2541'19.3' S, 51'44'38.6”' W, 9 Jan 2005, C. R. Moreira. MZUSP 68132, 12, 34.8-42.5 mm SL, Quatro Barras, rio Taquari, tributary of rio Capivari, rio Ribeira de Iguape basin, $2 \mathrm{~km}$ ahead of Morada do Silêncio Chaminé da Serra da Ordem Rosa Cruz, 2520'20"S, 48 55'46”'W, 10 Mar 2001, O. T. Oyakawa et al. MZUSP 68135, 3, 38.7-44.9 mm SL, Quatro Barras, rio Taquari, tributary of rio Capivari, rio Ribeira de Iguape basin, $2 \mathrm{~km}$ ahead of Morada do Silêncio Chaminé da Serra da Ordem Rosa Cruz, 2520'42"S, 48 56'12"W, 10 Mar 2001, O. T. Oyakawa et al. MZUSP 68136, 8, 32.8-41.4 mm SL, Quatro Barras, rio Taquari, tributary of rio Capivari, rio Ribeira de Iguape basin, in front of Morada do Silêncio Chaminé da Serra da Ordem Rosa Cruz, 2519'54" S, 4855'36" W, 10 Mar 2001, O. T. Oyakawa et al. MZUSP 68140, 13, 44.0-61.1 mm SL, Quatro Barras, rio Taquari, tributary of rio Capivari, rio Ribeira de Iguape basin, $2 \mathrm{~km}$ à frente do Rosa Cruz, 2520'42" S, 48 $56^{\prime} 14^{\prime \prime} \mathrm{W}$, 10 Mar 2001, O. T. Oyakawa et al. MZUSP 68142, 25 (2 cs) 32.5-56.8 mm SL, Quatro Barras, rio Taquari, tributary of rio Capivari, rio Ribeira de Iguape basin, in front of Morada do Silêncio Chaminé da Serra da Ordem Rosa Cruz, 2520'20" S, 48 55'44" W, 10 Mar 2001, O. T. Oyakawa et al. MZUSP 68144, 16, 33.2-55.1 mm SL, Quatro Barras, rio Taquari, tributary of rio Capivari, rio Ribeira de Iguape basin, $2 \mathrm{~km}$ ahead of Rosa Cruz, 2520'42” S, 4856'14" W, 10 Mar 2001, O. T. Oyakawa et al.

Diagnosis. Characidium travassosi is a member of Clade C1 (Buckup, 1993b), which can be diagnosed from its congeners, except $C$. alipioi, $C$. amaila Lujan, AgudeloZamora, Taphorn, Booth \& López-Fernández, 2013, C. boavistae Steindachner, 1915, C. bolivianum Pearson, 1924; C. crandellii Steindachner, 1915; C. declivirostre Steindachner, 1915; C. fasciatum Reinhardt, 1867; C. gomesi Travassos, 1956, C. lauroi, C. grajahuense, C. helmeri Zanata, Sarmento-Soares \& Martins-Pinheiro, 2015, C. japuhybense, C. kamakan Zanata \& Camelier, 2015, C. pterostictum, C. oiticicai, C. purpuratum Steindachner, 1882, C. schubarti, C. timbuiense, and C. vidali by having the isthmus unscalled (vs. isthmus scaled). Characidium travassosi differs from all species included in Clade 1, except $C$. helmeri, by having 15-18 principal caudal-fin rays (vs. 19 principal caudal-fin rays), and 10-12 total pectoral-fin rays (vs. 13 or more total pectoral-fin rays), and from $C$. helmeri by having the body slender (body depth at dorsal-fin origin 15.9-23.5 vs. $23.8-30.9 \%$ in SL), tip of pectoral fin not reaching origin of pelvic fin ( $v s$. tip of pectoral fin reaching origin of pelvic fin), tip of pelvic fin not reaching beyond anus ( $v s$. tip of pelvic fin reaching well beyond anus, to origin of anal fin), supraorbital well 
developed (vs. supraorbital absent or vestigial), and by basicaudal spot on base of caudal-fin middle rays absent ( $v s$. present). Furthermore, the number of pored lateral-line scales in C. travassosi is usually higher than in C. helmeri (14-35 vs. 1322). Characidium travassosi further differs from all species in Clade $\mathrm{C} 1$ except $C$. japuhybense, C. helmeri, C. lauroi, $C$. oiticicai, and $C$. schubarti by the presence of spots or dashes on flank (vs. spots absent), and from C. japuhybense, C. helmeri, C. lauroi, C. oiticicai, and C. schubarti by having spots inconspicuous (Fig. 1a, b, c), triangular, or v-shaped (Fig. 1d, e), sometimes connected in forming w-shaped marks (vs. spots stout, small and rounded in C. japuhybense, C. lauroi, C. oiticicai and C. schubarti; or spots or dashes stout and vertically elongated in $C$. helmeri). Additionally, C. travassosi differs from all species in Clade $\mathrm{C} 1$, except $C$. helmeri and $C$. oiticicai, by the absence of the adipose fin ( $v s$. adipose fin present; in $C$. oiticicai, the adipose fin can be either absent, reduced or well-developed); and from all species in Clade $\mathrm{C} 1$, except $C$. helmeri and $C$. schubarti, by having the unscaled ventral surface restricted to a small area in the isthmus (vs. unscaled area extending from the isthmus to the area between the contralateral anterior pectoral-fin rays in $C$.japuhybense, $C$. lauroi, and $C$. oiticicai; unscaled area extending from isthmus, to the breast and around the pectoral fins in C. alipioi, C. amaila, C. boavistae, C. bolivianum, C. fasciatum, C. gomesi, C. grajahuense, C. kamakan, C. purpuratum, C. pterostictum, C. timbuiense, and $C$. vidali, and unscaled area extending from the isthmus to the belly in $C$. crandellii, and $C$. declivirostre).

Description. Morphometric data summarized in Table 1. Species of Characidium reaching $55.1 \mathrm{~mm}$ SL. Body fusiform. Dorsal profile moderately convex between tip of snout and dorsal-fin origin, gently arched at dorsal-fin base, almost straight between dorsal and caudal-fin bases. Ventral profile gently convex between anterior tip of dentary and anal-fin origin, slightly convex at anal-fin base; almost straight between anal and caudal-fin bases. Belly more strongly arched in females with ovaries well developed. Greatest depth of body at dorsal-fin origin.

Table 1. Morphometric data for Characidium travassosi, new species. Range values are for holotype (MZUSP 85940) and paratypes (MZUSP 68135, $\mathrm{n}=3 ; 68140, \mathrm{n}=10 ; 68142, \mathrm{n}=10 ; 68144, \mathrm{n}=10 ; 85938, \mathrm{n}=7$ ); N: total number of specimens examined; SD: Standard Deviation.

\begin{tabular}{|c|c|c|c|c|c|}
\hline Character & Holotype & $\mathrm{N}$ & Range & Mean & SD \\
\hline Total length (mm) & 42.1 & 41 & $35.7-68.8$ & 48.5 & \\
\hline Standard length $(\mathrm{mm})$ & 33.8 & 41 & $29.7-56.3$ & 39.6 & 6.3 \\
\hline \multicolumn{6}{|c|}{ Percentage of standard length } \\
\hline Head length & 23.8 & 41 & $23.8-26.7$ & 25.0 & 0.8 \\
\hline Prepectoral distance & 23.1 & 41 & $20.5-25.5$ & 23.1 & 0.9 \\
\hline Pectoral-fin height & 18.3 & 41 & $16.8-23.1$ & 19.9 & 1.5 \\
\hline Predorsal distance & 50.0 & 41 & $45.2-52.0$ & 48.4 & 1.3 \\
\hline Dorsal-fin height & 15.2 & 40 & $11.8-18.5$ & 14.9 & 1.5 \\
\hline Dorsal-fin base & 14.3 & 41 & $12.9-16.9$ & 14.6 & 0.9 \\
\hline Prepelvic distance & 52.0 & 41 & $46.7-55.2$ & 51.8 & 1.6 \\
\hline Pelvic-fin height & 10.5 & 41 & $8.6-14.3$ & 11.7 & 1.0 \\
\hline Preanal distance & 76.8 & 41 & 71.9-79.9 & 75.3 & 1.7 \\
\hline Anal-apex distance & 94.3 & 41 & $87.1-100.7$ & 93.6 & 2.3 \\
\hline Anus to anal-fin distance & 3.6 & 41 & $2.6-4.7$ & 3.6 & 0.5 \\
\hline Anal-fin height & 13.1 & 41 & $10.1-15.8$ & 13.3 & 1.1 \\
\hline Anal-fin base & 8.6 & 41 & $6.7-9.8$ & 7.7 & 0.6 \\
\hline Body width & 12.8 & 41 & $10.0-13.4$ & 11.5 & 0.9 \\
\hline Peduncle length & 18.9 & 41 & $15.2-20.5$ & 17.5 & 1.1 \\
\hline Body depth at dorsal-fin origin & 23.1 & 41 & $15.9-23.5$ & 20.0 & 2.0 \\
\hline Body depth at anal-fin origin & 17.5 & 41 & $12.2-17.5$ & 14.5 & 1.2 \\
\hline Body depth at caudal-fin peduncle & 12.1 & 41 & $10.2-12.5$ & 11.5 & 0.6 \\
\hline Head length $(\mathrm{mm})$ & 8.0 & 41 & $7.3-15.0$ & 9.9 & 1.6 \\
\hline \multicolumn{6}{|c|}{ Percentage of head length } \\
\hline Snout length & 23.8 & 41 & $19.5-26.3$ & 22.6 & 1.8 \\
\hline Snout-maxillary tip & 25.6 & 41 & $23.7-30.2$ & 26.5 & 1.7 \\
\hline Anterior naris-orbit & 8.3 & 41 & $6.8-10.6$ & 8.7 & 0.7 \\
\hline Posterior naris-orbit & 4.2 & 41 & $2.7-5.0$ & 3.8 & 0.5 \\
\hline Cheek & 10.4 & 41 & $6.5-11.3$ & 9.2 & 1.0 \\
\hline Orbital diameter & 25.9 & 41 & $22.1-29.4$ & 26.9 & 1.5 \\
\hline Interorbital diameter & 17.5 & 41 & $12.5-19.3$ & 15.7 & 1.7 \\
\hline
\end{tabular}


Snout short, gently rounded, its tip at level of inferior margin of eye. Mouth small, sub-terminal. Snoutmaxillary tip distance equal or slightly longer than eye diameter; maxilla reaching level of anterior margin of orbit. Orbit rounded or slightly elongated antero-dorsally; margin of orbit free. Cheek depth about one third of eye diameter. Nares distinctly separated; distance between nares shorter than distance between posterior naris and eye. Dermal flap along entire border of anterior naris, crescent-shaped and restrict to anterior margin of posterior naris. Parietal branch of supraorbital laterossensory canal absent. Fontanel limited anteriorly by frontals, posteriorly by parietals. Dentary teeth in two rows. Outer dentary teeth 5 (4), 7* (6), 8 (10), 9 (14), 10 (2), 11 (3), 12 (1), with three cusps, teeth increasing in size from lateral to medial. Inner dentary teeth in single row of several minute, conical teeth. Premaxillary teeth in single row. Premaxillary teeth 5 (3), $6^{*}(16), 7(20), 8$ (1), with three cusps, teeth increasing in size from lateral to medial. Maxillary teeth absent. Ectopterygoid teeth conical, 9 (2), in single row. Mesopterygoid teeth absent. Branchiostegal rays 5* (41); 4 attached to anterior ceratohyal (2). Gill rakers on first arch 11 (2).

Scales cycloid; parallel radii present on posterior field of scale. Lateral line usually complete; lateral series of scales 33 (1), 34 (15), 35* (19), 36 (4), 37 (1). Perforated scales in lateral line highly variable, 21 (2), 22* (1), 29 (1), 32 (1), 33 (1), 34 (15), 35 (16), 36 (4); some specimens (e.g., MCP 22605, 4 of 4; MHNCI 8603, 1 of 2; MZUSP 85938, 1 of 4) with all scales of lateral series perforated; other specimens (e.g., MCP 22606, 1 of 1; MZUSP 85938, 3 of 4) with only anterior scales perforated; one specimen (MZUSP 85938) with lateral line discontinuous. Scales above lateral line 4 (11), $5^{*}(30)$. Scales below lateral line $5^{*}(30), 6(10)$. Scales around caudal peduncle 13 (3), 14* (38). Pre-dorsal scales series irregularly distributed. Scales on pre-dorsal series 11 (14), 12* (22), 13 (5). Scales between anus and anal fin $2^{*}(38), 3$ (3). Isthmus lacking scales to anterior margin of cleithrum.

Pectoral-fin rays ii,6,ii (1), iii,5,ii (1), iii,6,ii (2), iii,7,i (6), iii,7,ii* (13), iii,8,i (11), iii,8,ii (5), iv,7,ii (1), iii,9,i (1). Pelvic-fin rays i,5,i (1), ii,5,i (1), i,6,i* (37), i,7,i (2). Dorsal-fin rays ii,8 (1), iii,8 (3), ii,9* (31), iii,9 (5), ii,10 (1); supranumerary element on first pterygiophore of dorsal fin 1 (1). Anal-fin rays i,6 (1), i,7 (1), ii,5 (4), ii,6* (32), iii,5 (3); supranumerary element on first pterygiophore of anal fin 1 (1). Principal caudal-fin rays i,6,7,i (1), i,7,7,i* (1), i,7,8,i (33), i,8,7,i (4), i,8,8,i (2). Adipose fin absent* (41).

Precaudal vertebrae 20 (2), 21 (1); total vertebrae 35 (1), 36 (1), 37 (1). Upper procurrent rays 6 (3); lower procurrent rays 6 (3). Hypurals 5 (3). Epurals 1 (1), 2 (1), 3 (1). Uroneural 1 (3).

Coloration. Preserved specimens with ground color of head and trunk tan. Cheek, distal portion of upper jaw, and ventral part of head pale; anterior portion of upper jaw, dorsal portion of snout and head brown. Dorsal half of flank darker than ventral; belly pale. Longitudinal stripe stout, extending from tip of snout to postero-dorsal angle of opercle on head, continuing along midbody dorsally to lateral line, not reaching scales on base of caudalfin rays. Eyes entirely black or with a small light ventral area. Humeral spot oval, vertically elongated, positioned over posttemporal and supracleithrum, overlapped by longitudinal stripe. Spot on base of caudal-fin middle rays absent. Vertical bars on body eight to nine, irregular distributed, and blurry along dorsal midline; not connected ventrally on caudal peduncle and belly. Inconspicuous spots on flank present, variable in position, number and form. Spots usually associated to primary bars, often numerous and present above and below vertical stripe (Fig. 1a, c, d, e), but in some specimens few and restricted to area below vertical stripe (Fig. 1b). Spots inconspicuous (Fig. 1a, b, c), triangular, or v-shaped (Fig. 1d, e), sometimes connected forming w-shaped marks (Fig. 1d, e).

Pelvic and anal-fins rays and interradial membranes hyaline. Pectoral-fin interradial membrane hyaline, and pectoral-fin rays with widely spaced melanophores, more concentrated on first, second, third and, sometimes, fourth, fifth and sixth rays. Dorsal-fin rays and interradial membrane mostly hyaline, except for two longitudinal dark stripes, parallel to fin base. Caudal fin with widely spaced melanophores, more concentrated on fin rays, forming inconspicuous marks. Spot at base medial caudal-fin rays absent.

Sexual dimorphism. No external dimorphism was observed.

Distribution. Characidium travassosi is only known from Paraná State, Brazil, in small cold-water creeks of the Mata Atlântica biome. It is known from the streams draining the west side of Serra da Esperança into rio Jordão, a tributary of the right bank of rio Iguaçu, rio Paraná Basin; and from rio Taquari, a small stream at Serra da Graciosa, which runs north into the rio Capivari, in the southern-most portion of the rio Ribeira de Iguape coastal system (Fig. 2).

Etymology. The specific name is dedicated to Haroldo Travassos, a deceased Brazilian ichthyologist, in recognition to the contributions he made for the taxonomy of the genus Characidium. Travassos worked at the Brazilian Museu Nacional, and was responsible for the description of 13 species of Characidium between 1944 and 1967, mostly from the South and Southeastern Brazil.

Conservation status. Considering that current relevant threats to the species were not detected in its distribution area, Characidium travassosi can be classified as Least Concern (LC), according to the International Union for Conservation of Nature categories and criteria (IUCN, 2014). 

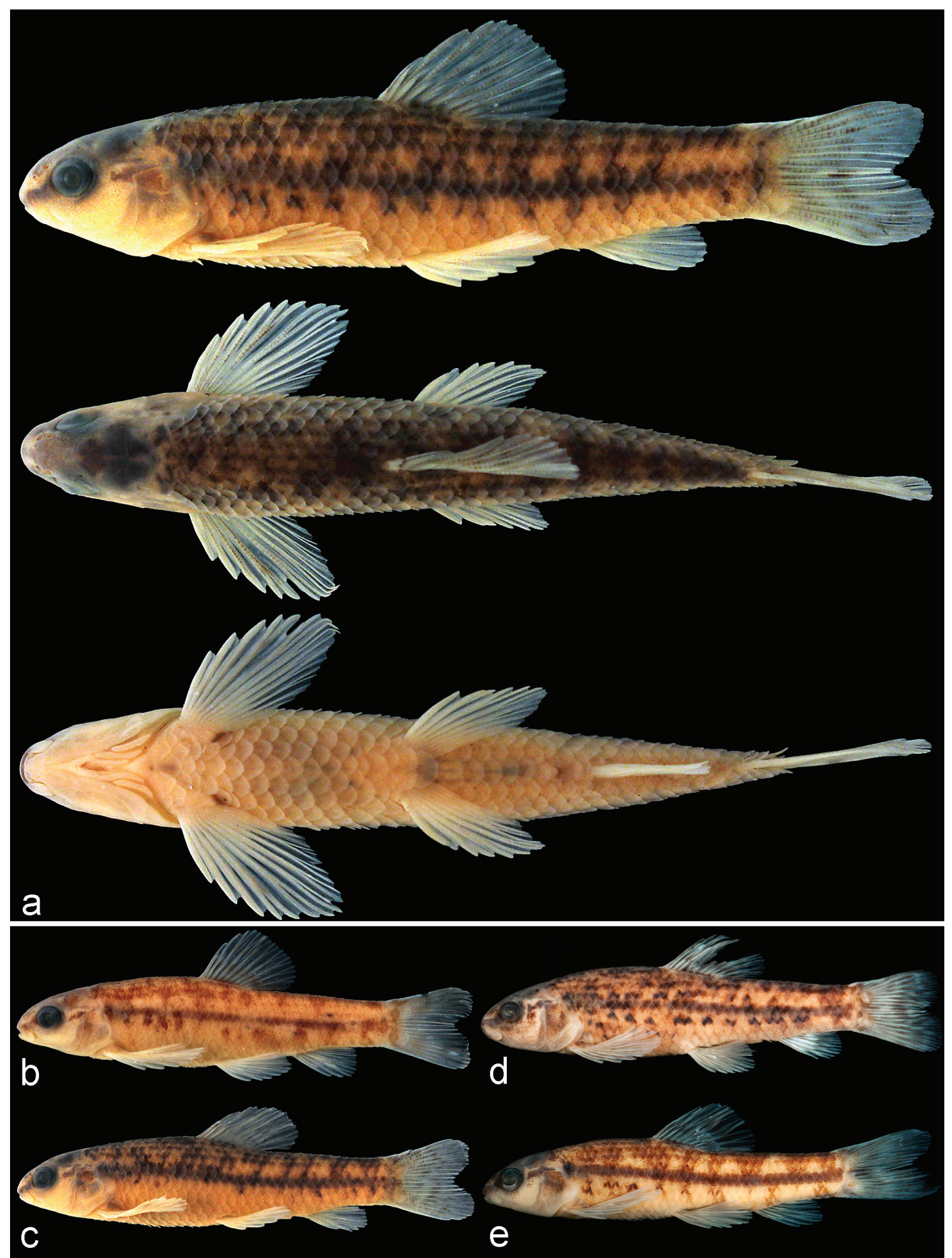

Fig. 1. Characidium travassosi, new species: (a) MZUSP 85940, $33.8 \mathrm{~mm}$ SL, holotype in lateral, dorsal and ventral views; stream tributary of rio Jordão, rio Iguaçu basin; (b) MZUSP 85938, $32.0 \mathrm{~mm}$ SL, and (c) MZUSP 85938, $32.9 \mathrm{~mm}$ SL, paratypes, rio Quadrado, rio Iguaçu basin; (d) MZUSP 68142, $56.3 \mathrm{~mm}$ SL, paratype, rio Taquari, tributary of rio Capivari, rio Ribeira de Iguape basin, (e) MZUSP 68144, $40.3 \mathrm{~mm}$ SL, paratype, rio Taquari tributary of rio Capivari, rio Ribeira de Iguape basin. 

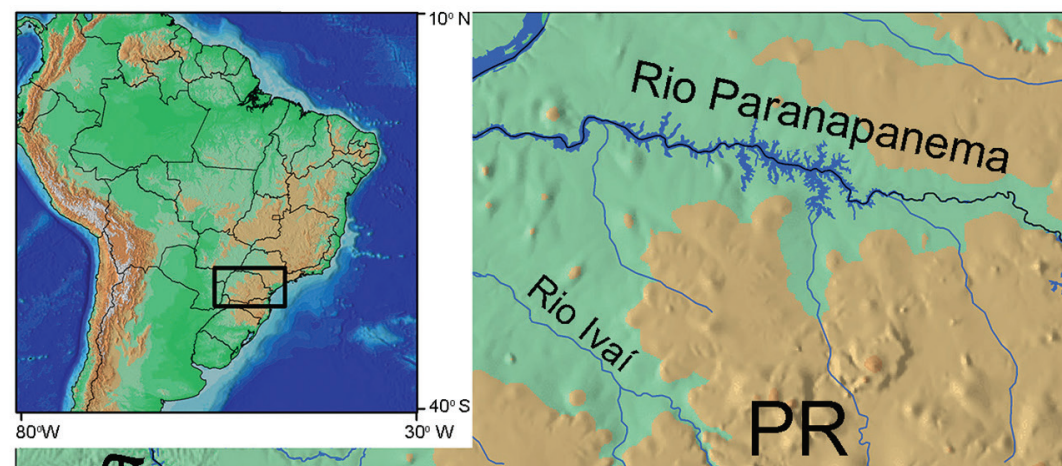

\section{SP}
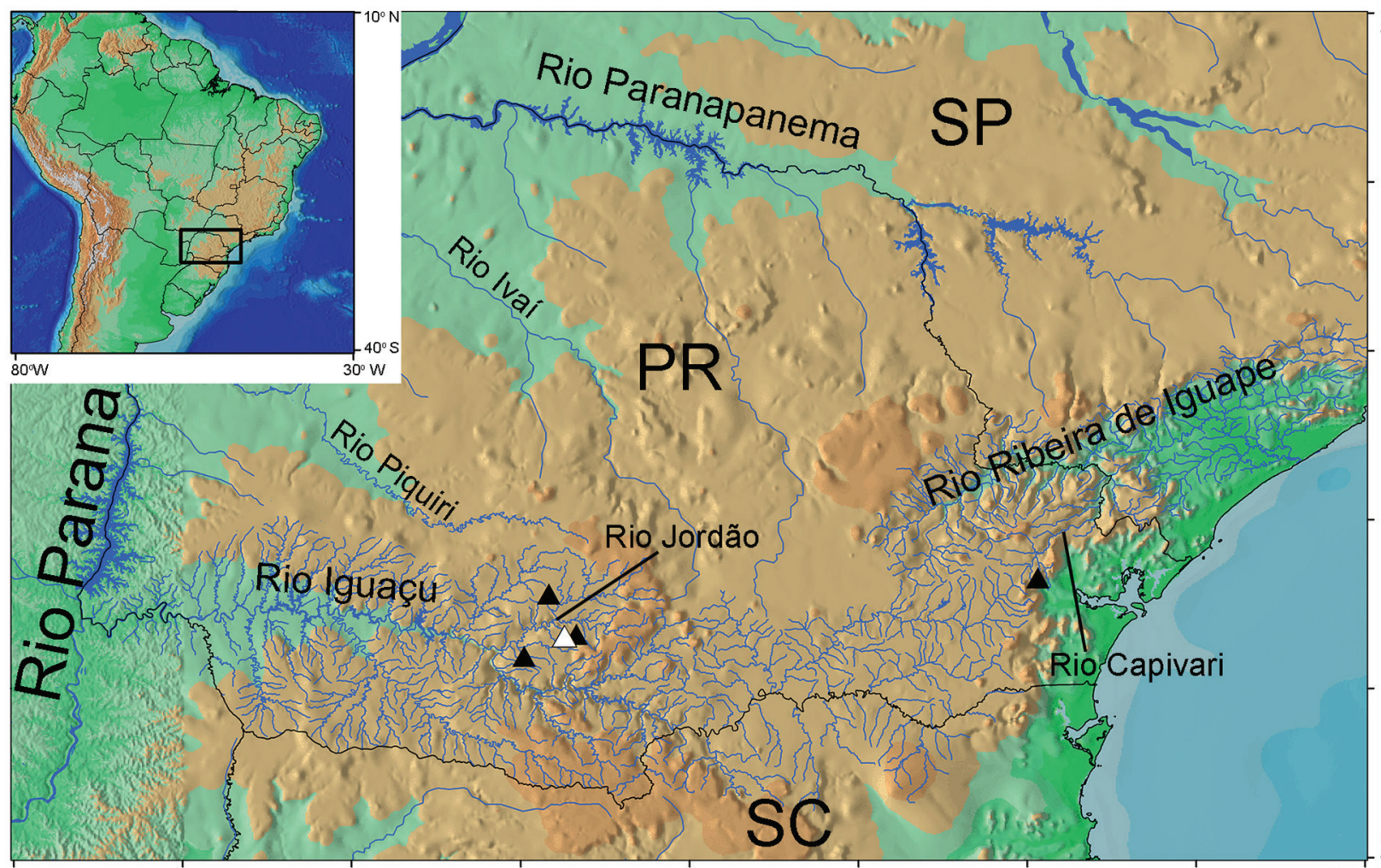

$55^{\circ} \mathrm{W}$

Fig. 2. Geographic distribution of Characidium travassosi. White triangle = type locality; black triangles = additional localities.

\section{Discussion}

The number of bony elements of the caudal fin is variable in C. travassosi, being reduced in some specimens (Fig. 3). The complete condition is to have six hypurals and three epurals supporting the principal caudal-fin rays, and the upper and lower procurrent rays, as in Characidium fasciatum (MZUSP 85938, Fig. 3d). Only a few specimens of C. travassosi (e.g., MZUSP 88142, Fig. 3a) have such condition, and other specimens have variation, including fusions and losses of caudal-fin bones. The number of epurals varies from one to three, being two the most frequent (e.g., MZUSP 88142 and 85938, Fig. 3b, c). The number of hypurals may be reduced to five or four, but with different combinations: in MZUSP 85938, the hypural four or five is missing or fused (Fig. 3c), and in MZUSP 88142 the hypurals one and two, and hypurals three and four are clearly fused (Fig. 3b). The malformation of the caudal-fin bones is correlated with the reduced number of caudal-fin rays.

Reduction in number of caudal-fin rays is a relatively common trend among characidiins, including five species of Characidium. Microcharacidium Buckup, 1993 includes three miniature species with only 17 principal caudal-fin rays (character 36, state 1 of Buckup, 1993b): M. eleotrioides (Géry, 1960), M. weitzmani Buckup, 1993, and M. gnomus Buckup, 2003. Zarske (1997) erected the genus Geryichthys to include G. sterbai and suggested a close relationship between Geryichthys and Microcharacidium based on the low number of caudal-fin rays, pectoral-fin rays, and lateral-line scales. The validity of Geryichthys, however, was previously questioned by Graça et al. (2008) and, although the species is valid, the genus should be considered as a junior synonym of Characidium. Characidium geryi was erroneously described as a Microcharacidium due to the low number of fin rays, also has 16-17 caudal-fin rays (Zarske, 1997). Other species of Characidium with relatively low number of caudal-fin rays are C. helmeri with 18-19 caudal-fin rays, C. mirim Netto-Ferreira, Birindelli \& Buckup, 2013 with 15-17 caudal-fin rays, C. nupelia Graça, Pavanelli \& Buckup, 2008 with 17-19 caudal-fin rays, and C. xavante da Graça, Pavanelli \& Buckup, 2008 with 18-19 caudal-fin rays (Graça et al., 2008; Netto-Ferreira et al., 2013; Zanata et al., 2015).

Characidium travassosi also has a low number of pectoral-fin rays (10-12) compared to most of its congeners, which have 13 or more. The smaller range in number of pectoral-fin rays is not a discrete character and, therefore, it is difficult to coded it as a phylogenetic character. It does not seem to unique to any particular group of species of Characidium, since the following species also have a low count of pectoral-fin rays: C. bahiense Almeida, 1971 has 9-11 pectoral-fin rays; C. bimaculatum Fowler, 1941, 
with 12 pectoral-fin rays; C. etzeli Zarske \& Géry, 2001, with 11-12 pectoral-fin rays; C. geryi, with 8-9 pectoralfin rays; C. heinianum Zarske \& Géry, 2001, with 10 pectoral-fin rays; $C$. helmeri, with $8-12$ pectoral-fin rays; C. mirim, with 9-11 pectoral-fin rays; $C$. nupelia, with 11-13 pectoral-fin rays; $C$. sterbai, with 9-10 pectoral-fin rays; and C. xavante, with 11-13 pectoral-fin rays (Fowler, 1941; Almeida, 1971; Zarske, 1997; Zarske \& Géry, 2001; Graça et al., 2008; Netto-Ferreira et al., 2013; Zanata et al., 2015). The species of Elachocharax, Klausewitzia, Microcharacidium, and Odontocharacidium have nine or fewer pectoral-fin rays (Buckup, 1993b: Clade 5; character 29).

Absence of an adipose fin is another reductive character widespread within the species of Characidium.
Besides C. travassosi, the adipose fin is absent in C. helmeri, C. mirim, C. nana, C. nupelia, C. stigmosum, C. sterbai, and C. xavante (Zarske, 1997; Melo \& Buckup, 2002; Graça et al., 2008; Netto-Ferreira et al., 2013; Mendonça \& Netto-Ferreira, 2015), reduced or absent in C. vestigipinne (Buckup \& Hahn, 2000), well-developed or absent in C. lauroi (Travassos, 1949a; Characidium sp. 1 in Lima, 1997), and well-developed, reduced or absent in C. oiticicai (Travassos, 1967; Ribeiro et al., 2006; Marceniuk et al., 2011; our data). The adipose fin is also reduced in Microcharacidium weitzmani Buckup, 1993, and absent in Elachocharax geryi Weitzman \& Kanazawa, 1978, Poecilocharax bovaliorum Eigenmann, 1909, and P. weitzmani Géry, 1965 (Eigenmann, 1909; Géry, 1977; Weitzman \& Kanazawa, 1978; Buckup, 1993a).

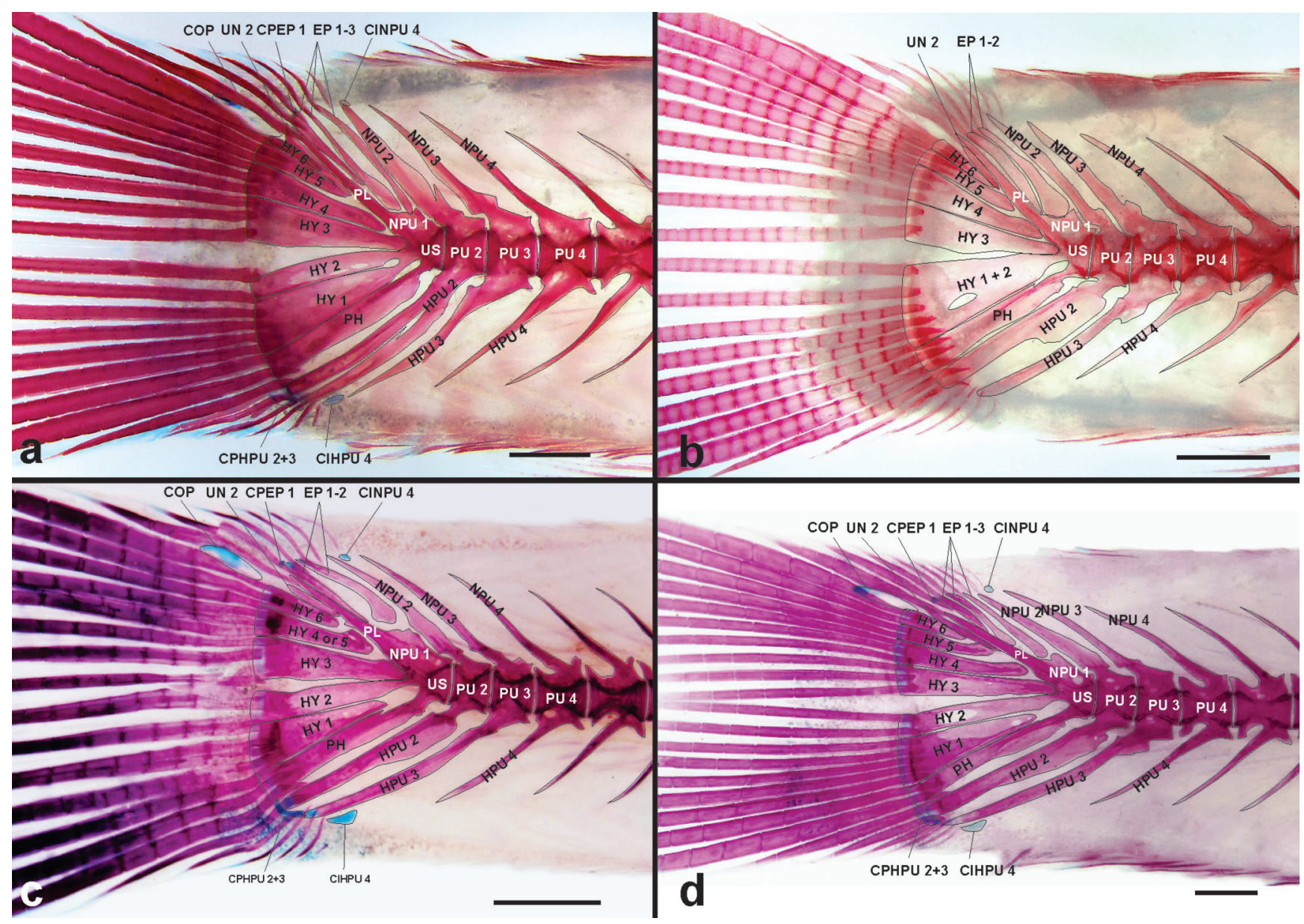

Fig. 3. Caudal-fin bony elements in Characidium travassosi $(\mathrm{a}=$ MZUSP $88142,45.0 \mathrm{~mm}$ SL; $\mathrm{b}=$ MZUSP 68142 , $45.6 \mathrm{~mm} \mathrm{SL}$; c = MZUSP 85938, $29.8 \mathrm{~mm} \mathrm{SL}$ ), and Characidium fasciatum (d = MZUSP 85995, $27.9 \mathrm{~mm}$ SL). Scale bar equals $1 \mathrm{~mm}$. Specimens illustrated in a, c and d were double stained for bone and cartilage; specimen b was only stained for bone. The epineurals and epipleurals were removed during dissection; numbering of hypurals does not necessarily imply homology. Abbreviations are as follows: EP, epurals; HPU, haemal spine of pleural centrum; NPU, neural spine of pleural centrum; HY, hypural; NA, neural arch; NU, neural spine of ural centrum; PH, parahypural; PL, pleurostyle; PU, pleural centrum; US, urostyle; CIHPU, inter-neural spine of cartilage of pleural centrum; CPHPU, post-neural spine cartilage of pleural centrum; COP, opisthural cartilage; CPEP, post-epural cartilage; CINPU, interneural spine cartilage of pleural centrum. 
Characidium lauroi group of species. The group was firstly proposed by Travassos (1955a: 371, 1967: 45), without an explicit diagnosis or establishment of its taxonomic limits. In addition to $C$. travassosi, the $C$. lauroi group includes the following four species: C. lauroi, C. japuhybense, C. oiticicai, and C. schubarti (Melo, 2001; Buckup \& Melo, 2002).

These species occur in small streams draining the Serra do Mar mountain range from $22^{\circ} 17^{\prime} \mathrm{S}$ to $25^{\circ} 48^{\prime} \mathrm{S}$ and $45^{\circ} 15^{\prime} \mathrm{W}$ to $48^{\circ} 30^{\prime} \mathrm{W}$, along the eastern areas of the Brazilian states of Paraná, São Paulo and Rio de Janeiro. Characidium lauroi occurs in the tributaries of the Medium and Upper rio Paraíba do Sul drainage; C. japuhybense, in coastal streams from the Ilha Grande Bay to the State of São Paulo, including a few isolated populations in the streams of the Ilha Grande and the Ilha de São Sebastião (Ilha Bela); C. schubarti, in tributaries of rio Paranapanema; and C. oiticicai, in headwaters of rio Tietê. Remarkably, with the exception of $C$. lauroi, all other species of the group also occur in the rio Ribeira de Iguape coastal drainage (Travassos, 1949a, 1949b, 1955a, 1967; Oyakawa et al., 2006; Scaramuzza et al., 2011; Lima, 1997; Ribeiro et al., 2006; Marceniuk et al., 2011; our data)

Characidium lauroi group is characterized by three derived characteristics: parietal branch of supraorbital sensory canal absent; vertical bars irregular distributed, fainted or absent, not connected ventrally in caudal peduncle; and presence of small spots on the ventral portion of flank. Although those characteristics represent putative synapomorphies, the absence of the parietal branch, and the poorly marked vertical bars are not unique to the $C$. lauroi group. The presence of dots on sides of body, however, is very characteristic and unique to the group.

The parietal branch of supraorbital sensory canal is also absent in the species included in Clade 4, and in the all species included in the genera Elachocharax, Microcharacidium, and Odontocharacidium (Buckup, 1993b; Melo \& Buckup, 2002; Netto-Ferreira et al., 2013; Mendonça \& Netto-Ferreira, 2015). This character distribution indicates that this character probably evolved multiple, independent times within the family Crenuchidae.

Within the Characidium lauroi group, when present, the transversal bars vary from eight to 11 . The presence of bars varies ontogenetically, with juveniles of $C$. japuhybense, C. lauroi, C. schubarti and most specimens examined of C. oiticicai having bars well marked, but the adults of $C$. japuhybense having bars poorly marked, or completely absent in C. lauroi, C. schubarti and C. oiticicai. Other species of Characidium that have faded vertical bars in adults are $C$. gomesi, C. fasciatum, C. mirim, C. pellucidum, C. satoi Melo and Oyakawa, 2015, C. stigmosum, and C. xanthopterum Silveira, Langeani, da Graça, Pavanelli and Buckup, 2008, and the bars can be completely absent as in C. summus Zanata \& Ohara, 2015 (Eigenmann, 1909; Buckup, 1992; Buckup \& Melo, 2002; Silveira et al., 2008;
Netto-Ferreira et al., 2013; Melo \& Oyakawa, 2015; Zanata \& Ohara, 2015).

The small dots on sides of body develop ontogenetically, on the ventral tip of the transversal bars: as the fish grows, the bars fade and the dots become more evident. In C. travassosi, the dots are inconspicuous; in $C$. japuhybense the dots are well-marked, circular, and more concentrated in the ventral tip of transversal bars; and in the adults of C. lauroi, C. oiticicai and C. schubarti the dots are well-marked, numerous, and irregularly distributed ventrally and dorsally to the lateral line.

Other species of Characidium having marks on body are C. helmeri, C. longum Taphorn, Montaña and Buckup, 2006, C. pellucidum Eigenmann, 1909, C. pteroides Eigenmann, 1909, and C. stigmosum. Characidium longum, C. pellucidum, C. pteroides are members of Clade C5 (Buckup, 1993b), and restricted to the northern part of South America. The disposition and shape of the spots in those species is different to the species of the C. lauroi group: in Characidium longum and C. pellucidum spots are restricted to the area along the lateral midline and dorsum of body, and $C$. pteroides has distinguishing reddishbrown crescents-shaped marks irregularly distributed on body (Eigenmann, 1912; Taphorn et al., 2006). Characidium stigmosum have dots elliptical and much larger when compared to the species of the $C$. lauroi group (Melo \& Buckup, 2002). In Characidium helmeri, the marks are formed by melanophores more concentrated on the posterior half of scales, forming vertically elongated, narrow spots or dashes (Zanata et al., 2015).

Characidium lauroi group shares the synapomorphies of Clade C1 of Buckup (1993b), which includes the species of Characidium with naked isthmus. Seven species were originally included in Clade C1 by Buckup (1993b): C. boavistae; C. bolivianum; C. crandellii; C. declivirostre; C. fasciatum; C. gomesi, and $C$. purpuratum. Later, the following five species were hypothesized as members of clade C1, C. alipioi, C. amaila, C.japuhybense, C. kamakan, and C. timbuiense (Travassos, 1946, 1955b; Buckup \& Reis, 1997; Lujan et al., 2013; Zanata \& Camelier, 2015). Five additional species of Characidium also have unscaled isthmus and are putative members of Clade C1: C. grajahuense, C. helmeri, C. macrolepidotus Peters, 1868, C. pterostictum, and C. vidali (Travassos, 1944, 1967; Gomes, 1947; Géry et al., 2001; Zanata et al., 2015).

Within the species of the $C$. lauroi group, the unscaled area of the isthmus is restricted to a smaller area than in the remaining species of Clade C1 (Buckup, 1993b). In C. travassosi it is restricted to the isthmus and anterior margin of the cleithrum; in C. lauroi, C. japuhybense and C. oiticicai, it extends to the level of the three anterior pectoral-fin rays, but not surrounding the pectoral fins; and $C$. schubarti has this character variable, with both conditions mentioned above (Travassos, 1949a, 1949b, 1955a, 1967; our data). 
Characidium hasemani Steindachner, 1915 and C. lanei Travassos, 1967 have naked isthmus, but according to the phylogenetic hypothesis proposed by Buckup (1993b), they fit elsewhere in the phylogeny. Noteworthy, $C$. interruptum Pellegrin, 1909 was referred as having unscaled isthmus (Buckup, 1993b; Melo \& Buckup, 2002), but all specimens examined by us have the isthmus completely scaled, suggesting that this character needs to be reevaluated.

The two additional synapomorphies of Clade C1 (Buckup, 1993b) are variable among the species of the C. lauroi group. The reduction or absence of postcleithrum 1 (character 23, Buckup, 1993b) is only present in C. lauroi, C. oiticicai and C. schubarti, and the reduction of the fontanel and exclusion of the frontals from its anterior margin (character 8, Buckup, 1993b) is present in C. oiticicai and C. schubarti. These variations reinforce the need for further phylogenetic studies focused on the species of Characidium, with the inclusion of a larger number of species and new characters (Buckup, 1993b; Netto-Ferreira et al., 2013; Zanata \& Camelier, 2015).

Comparative Material Examined. Material examined in addition to Melo \& Oyakawa (2015). All from Brazil: Characidium lauroi: MNRJ 5530, 1 (paratype) $56.0 \mathrm{~mm} \mathrm{SL}$, Rio de Janeiro, Rezende, rio das Pedras. MNRJ 6118-24, 7, 54.4-43.0 mm SL, MNRJ 13701, 202 (4 cs), 32.7-71.7 mm SL, MNRJ 13703,76, 22.3$33.3 \mathrm{~mm}$ SL, MNRJ 14404, 54 (2 cs), 30.1-57.7 mm SL, MNRJ 14408, 4 (1 cs), 47.2-51.9 mm SL, MNRJ 17432, 3, 33.2-37.1 mm SL, MNRJ 21687, 45. 6 mm SL, MCP 19863, 5, 29.0-45.0 mm SL, MCP 19864, 38, 36.0-25.6 mm SL, MZUSP 68800, 10, 27.0-46.9 $\mathrm{mm}$ SL, Rio de Janeiro, Teresópolis, rio Paquequer. MNRJ 11688, 1, $50.7 \mathrm{~mm}$ SL, MNRJ 17443, 1, $45.4 \mathrm{~mm}$ SL, MNRJ 19402, 1, $49.57 \mathrm{~mm} \mathrm{SL}$, Rio de Janeiro, Itatiaia, rio Pirapetinga. MNRJ 12843, 13 (2 cs), 47.5-63.6 mm SL, MNRJ 14025, 1, $30.3 \mathrm{~mm} \mathrm{SL}$, MNRJ 15036, 2, 59.7-51.5 mm SL, MNRJ 15043, 1, $51.2 \mathrm{~mm}$ SL, MNRJ 19316, 3 (1 cs), 70.2-80.7 mm, MNRJ 20052, 3, 27.2-35.7 $\mathrm{mm}$, Rio de Janeiro, Petrópolis, rio Paquequer. MZUSP 104206, 8, 47.8-51.8 mm SL, São Paulo, Pindamonhangaba. MZUSP 49110, 24 (2 cs), 48.4-56.3 mm SL, MZUSP 49119, 4, 33.0-50.3 mm SL, São Paulo Pindamonhangaba, rio Ribeirão Grande. MZUSP 51933, 5, 37.5-53.6 mm SL, São Paulo, Silveira, rio da Bocaina. MZUSP 109819, 41 (1 cs), 32.5-47.4 mm SL, MZUSP 109826, 14 (3 cs), 37.1-60.2 mm SL, São Paulo, Bananal. UFRJ 616, 3 (2 cs), 45.5-49.6 mm SL, Rio de Janeiro, Itatiaia, rio Bonito. UFRJ 35494, 3, 34.5-71.15 mm SL, São Paulo, Monteiro Lobato rio Bujurquinha. Characidium japuhybense: MNRJ 5191-5193, 5195-5201, 5205, 5207, 12 (all paratypes in the same jar), 40.4$53.1 \mathrm{~mm}$ SL, MNRJ 11693, 21 (1 cs), 27.2-30.3 mm SL, Rio de Janeiro, Angra dos Reis, rio Japuíba. MNRJ 11448, 87, 37.344.0 mm SL, MNRJ 11449, 5, 45.3-38.4 mm SL, MNRJ 11450, 5, 39.5-40.4 mm SL, MNRJ 11692, 24, 32.4-52.1 mm SL, Angra dos Reis, Rio de Janeiro, rio Zungú. MNRJ 13787, 47 (2 cs), MNRJ 13789, 35, 23.0-41.5 mm SL, MNRJ 13790, 27, 25.8-44.3 mm SL, MNRJ 13794, 36, 31.3-41.8 mm SL, MNRJ 11444, 38, 25.4-53.4 mm SL, MNRJ 19595, 1, 45.6 mm SL, Rio de Janeiro, Paraty, rio Parati-Mirim. MNRJ 19193, 3, 19.8-22.6 mm SL, Rio de Janeiro, Angra dos Reis, rio Perequê. MNRJ 19595, 1, $54.0 \mathrm{~mm}$ SL, Rio de Janeiro, Paraty, rio Forquilha. MNRJ 20596, 1, 19.6 mm SL, MNRJ 20600, 1, 55.4 mm SL, MNRJ 20876, 2, 49.15$50.9 \mathrm{~mm}$ SL, Rio de Janeiro, Ilha Grande, Angra dos Reis, rio Andorinha. MZUSP 39994, 2, 24.8-34.5 mm SL, MZUSP 83447, 1, 57.0 mm SL, MZUSP 90376, 41 (1 cs), 35.8-58.6 mm SL, São Paulo, Ubatuba. MZUSP 60251, 5, 54.4-37.7 mm SL, São Paulo, Barra do Turvo, rio Ribeira de Iguape. MZUSP 61770, 4, 51.7$49.9 \mathrm{~mm}$ SL, MZUSP 61774, 3, 55.5-49.2 mm SL, MZUSP 61788, 7, 59.4-37.7 mm SL, MZUSP 62014, 2, 60.0-42.2 mm SL, MZUSP 61797, 9 (2 cs), 47.7-23.5 mm SL, MZUSP 62018, 8, 49.4-31.0 mm SL, MZUSP 62036, 3, 61.7-49.1 mm SL, MZUSP 62037, 3, 45.9$34.3 \mathrm{~mm}$ SL, São Paulo, Iporanga, rio Ribeira de Iguape. MZUSP 90372, 16, 33.7-51.3 mm SL, São Paulo, Cubatão. MZUSP 107319, 3, 36.2-42.2 mm SL, São Paulo, Ilhabela, São Sebastião. Characidium schubarti: MNRJ 8853, 50,3 mm SL (holotype), Paraná, border of Joaquim Murtinhos and Jaguariaíva; MNRJ 8852, 8854-8857, 4 (all paratypes in the same jar), $45.7-56.4 \mathrm{~mm}$ SL, collected with holotype. MZUSP 53151, 59, 55.7-22.3 mm SL, MZUSP 53152, 11, 44.0-21.5 mm SL, MZUSP 53142, 11, 54.7$32.8 \mathrm{~mm}$ SL, MZUSP 54911, 5, 42.0-39.5 mm SL, MZUSP 62405, 9, 52.6-34.9 mm SL, São Paulo, Apiaí, rio Ribeira de Iguape. MZUSP 51060, 4, 43.26-37.09 mm SL, MZUSP 51874, 7, 46.4$41.3 \mathrm{~mm}$ SL, MZUSP 51884, 1, $48.8 \mathrm{~mm}$ SL, MZUSP 51891, 2, 44.4-44.0 mm SL, MZUSP 51892, 1, 21.8 mm SL, MZUSP 51904, 5, 49.8-35.3 mm SL, MZUSP 51906, 5, 40.5-26.2 mm SL, MZUSP 52599, 16, 39.1-26.6 mm SL, MZUSP 52585, 1, 26.32 mm SL, São Paulo, Ribeirão Grande, rio Paranapanema basin. MZUSP 55014, 1, $33.4 \mathrm{~mm}$ SL, São Paulo, Capão Bonito, rio Paranapanema basin. MNRJ 19306, 3, 45.6-33.3 mm SL, Paraná, Jaguariaíva, rio Paranapanema basin. MNRJ 11454, 74, 40.7-19.0 mm SL, MNRJ 11455, 4, 54.6-18.5 mm SL, São Paulo, Itatinga rio Paranapanema basin. MNRJ 11457, 29, 64.5-39.9 mm SL, MNRJ 11458, 28 (2 cs), 37.2-18.6 mm SL, MNRJ 11462, 1. 46.5 mm SL, MNRJ 11456, 7, 38.9-21.6 mm SL, MNRJ 11686, 1, 45.2 mm SL, MNRJ 19394, 1, $40.3 \mathrm{~mm}$ SL, MNRJ 1999, 1, $19.0 \mathrm{~mm}$ SL, MNRJ 20244, 4, 32.4-24.4 mm SL, São Paulo, Botucatu, rio Paranapanema basin. Characidium oiticicai: MNRJ 20102, 5, 29.6-40.3 mm SL, São Paulo, Biritiba-Mirim, rio Biritiba-Açu drainage. MNRJ 5787, 3, 34.7-46.1 mm SL, USNM 288896, 1, 50.2 mm SL, MZUSP 54912, 8, 62.5-32.4 mm SL, São Paulo, Iporanga, rio Ribeira de Iguape basin. MZUSP 54909, 19, 58.4-28.3 mm SL, MZUSP 54975, 36, 57.8-25.8 mm SL, São Paulo, Apiaí, rio Ribeira de Iguape basin. MZUSP 26870, 13, 31.4-67.2 mm SL, MZUSP 78094, 2, 27.460.7 mm SL, MZUSP 86961, 2, 41.1-46.8 mm SL, São Paulo, Salesópolis, rio Claro. USNM 289989, 1, 52.9 mm SL, São Paulo, Santo André, Ribeirão Grande.

\section{Acknowledgements}

For loans and specimens we thank Roberto Reis (MCP), Mario de Pinna, Michel Gianeti (MZUSP), Oscar Shibatta (MZUEL), Susan Jewett, Sandra Raredon, Richard Vari (USNM), Wilson Costa (UFRJ), and Vinícius Abilhoa (MHNCI). We would like to thank M. Marinho (MZUSP) for data and information of the types of C. sterbai, 
C. Zawadzki (UEM) for helping us to obtain selected references. Part of the original research was conducted by MRSM at the Museu Nacional, Universidade Federal do Rio de Janeiro, with a graduate fellowship from Coordenação de Aperfeiçoamento de Pessoal de Nível Superior (CAPES). Additional grants supporting this study were provided to MRSM (Fundação de Amparo à Pesquisa do Estado de São Paulo - FAPESP, 2014/15168-7); PAB (Conselho Nacional de Desenvolvimento Científico e Tecnológico - CNPq, 307610/2013-6, 476822/2012-2) and (Fundação Carlos Chagas Filhos de Apoio a Pesquisa do Estado do Rio de Janeiro - FAPERJ, E-26/111.404/2012); and OTO (FAPESP, 00/04300-9).

\section{References}

Almeida, V. G. 1971. Descrição de uma nova espécie do gênero Characidium (Pisces, Characidae). Papéis Avulsos de Zoologia, 25: 111-119.

Baumgartner, G., C. S. Pavanelli, D. Baumgartner, A. G. Bifi, T. Debona \& V. A. Frana. 2012. Peixes do baixo rio Iguaçu. Maringá, Eduem, 203p.

Bizerril, C. R. S. F. \& P. B. S. Primo. 2001. Peixes de Águas Interiores do Estado do Rio de Janeiro. Rio de Janeiro, FEMAR - SEMADS, 417p.

Buckup, P. A. 1992. Redescription of Characidium fasciatum, type species of the Characidiinae (Teleostei, Characiformes). Copeia, 1992: 1066-1073.

Buckup, P. A. 1993a. Review of the characidiin fishes (Teleostei: Characiformes), with description of four new genera and ten new species. Ichthyological Exploration of Freshwaters, 4: 97-154.

Buckup, P. A. 1993b. Phylogenetic interrelationships and reductive evolution in Neotropical charadidiin fishes. Cladistics, 9: 305-341.

Buckup, P. A. 1999. Sistemática e biogeografia de peixes de riachos. Pp. 91-138. In: Caramaschi, E. P., R. Mazzoni \& P. R. Peres-Neto (Eds.). Ecologia de Peixes de Riachos. Série Oecologia Brasiliensis, vol. VI. Rio de Janeiro, PPGE-UFRJ.

Buckup, P. A. \& R. E. Reis. 1997. Characidiin genus Characidium (Teleostei, Characiformes) in Southern Brazil, with description of three new species. Copeia, 1997: 531-548.

Buckup, P. A. \& L. Hahn. 2000. Characidium vestigipinne: a new species of Characidiinae (Teleostei, Characiformes) from southern Brazil. Copeia, 2000: 150-155.

Buckup, P. A. \& M. R. S. Melo. 2002. Case study: phylogeny and distribution of fishes of the Characidium lauroi group as indicators of climate change in southeastern Brazil. Pp.193195. In: Lovejoy, T. E. \& L. Hannah (Eds.). Climate change and biodiversity. New Haven, Yale University Press, 418p.

Eigenmann, C. H. 1909. Reports on the expedition to British Guiana of the Indiana University and the Carnegie Museum, 1908. Report no. 1. Some new genera and species of fishes from British Guiana. Annals of the Carnegie Museum, 6: 4-54.

Eigenmann, C. H. 1912. The freshwater fishes of British Guiana, including a study of the ecological grouping of species, and the relation of the fauna of the plateau to that of the lowlands. Pittsburgh, Carnegie Institute, 597p. (Memoirs of Carnegie Museum, vol. 5).

Eschmeyer, W. N., R. Fricke \& R. van der Laan (Eds.). 2016. Catalog of fishes: genera, species, references, California Academy of Sciences, California. Available from: http://researcharchive. calacademy.org/research/ichthyology/catalog/fishcatmain.asp (Date of access - 10 April 2016).

Fowler, H. W. 1941. A collection of fresh-water fishes obtained in eastern Brazil by Dr. Rodolpho von Ihering. Proceedings of the Academy of Natural Sciences of Philadelphia, 93: 123-336.

Fujita, K. 1990. The caudal skeleton of teleostean fishes. Tokyo, Tokai University Press, $897 \mathrm{p}$.

Géry, J. 1977. Characoids of the World. Neptune City, THF Publications, 672p.

Géry, J., A. Zarske \& H. J. Paepke. 2001. Supplementary descriptions of two overlooked fish taxa, Leporinus macrolepidotus Peters, 1868, and Nanognathus borellii Boulenger, 1895, actually members of the genus Characidium Reinhardt, 1866 (Teleostei: Characiformes: Characidiidae). Zoologische Abhandlungen, Staatliches Museum für Tierkunde in Dresden, 51: 23-31.

Gomes, A. L. 1947. A small collection of fishes from Rio Grande do Sul, Brazil. Miscellaneous Publications, Museum of Zoology, University of Michigan, 67: 1-39.

Graça, W. J., C. S. Pavanelli \& P. A. Buckup. 2008. Two new species of Characidium (Characiformes: Crenuchidae) from Paraguay and Xingu river basins, state of Mato Grosso, Brazil. Copeia, 2008: 326-332.

IUCN Standards and Petitions Subcommittee. 2014. Guidelines for using the IUCN red list categories and criteria, version 11, Standards and Petitions Subcommittee, Switzerland. Available from: RedListGuidelines.pdf http://www. iucnredlist.org/documents/RedListGuidelines.pdf (Date of access - 20 May 2016).

Leitão, R. P. \& P. A. Buckup. 2014. A new species of Characidium (Characiformes: Crenuchidae) from coastal basins of Serra do Mar, Southeastern Brazil. Copeia, 2014: 14-22.

Lima, R. S. 1997. Ictiofauna do alto curso do rio Paraíba do Sul. Unpublished M. Sc. Thesis, Universidade de São Paulo, São Paulo, 221p.

Lujan, N. K., H. Agudelo-Zamora, D. C. Taphorn, P. N. Booth \& H. López-Fernández. 2013. Description of a new, narrowly endemic South American darter (Characiformes: Crenuchidae) from the Central Guiana Shield highlands of Guyana. Copeia, 2013: 454-463.

Marceniuk, A. P., A. W. S. Hilsdorf \& F. Langeani. 2011. A ictiofauna de cabeceiras do rio Tietê, São Paulo, Brasil. Biota Neotropica, 11: 217-236.

Melo, M. R. S. 2001. Sistemática, filogenia e biogeografia do grupo Characidium lauroi Travassos, 1949 (Crenuchidae, Characiformes). Unpublished M. Sc. Thesis, Universidade Federal do Rio de Janeiro, Rio de Janeiro, 95p.

Melo, M. R. S. \& P. A. Buckup. 2002. Characidium stigmosum (Characiformes: Crenuchidae): a new species of characidiin fish from central Brazil. Copeia, 2002: 988-993. 
Melo, M. R. S. \& O. T. Oyakawa. 2015. A new species of Characidium Reinhardt (Characiformes, Crenuchidae) with a distinctively dimorphic male. Copeia, 103: 281-289.

Mendonça, M. B. \& A. L. Netto-Ferreira. 2015. New species of Characidium (Characiformes: Crenuchidae) from the rio Tapajós and rio Xingu drainages, Pará, Brazil. Zootaxa, 4021: 187-194.

Menezes, N. A., S. H. Weitzman, O. T. Oyakawa, F. T. C. Lima, R. M. Castro \& M. J. Weitzman. 2007. Peixes de água doce da Mata Atlântica: lista preliminar das espécies e comentários sobre conservação de peixes de água doce neotropicais. São Paulo, Museu de Zoologia da Universidade de São Paulo, 407 p.

Netto-Ferreira, A. L., J. L. O. Birindelli \& P. A. Buckup. 2013. A new miniature species of Characidium Reinhardt (Ostariophysi: Characiformes: Crenuchidae) from the headwaters of the rio Araguaia, Brazil. Zootaxa, 3664: 361-368.

Oyakawa, O. T., A. Akama, K. C. Mautari \& J. C. Nolasco. 2006. Peixes de riachos da Mata Atlântica. São Paulo, Editora Neotropica, 204 p.

Ribeiro, A. C.; F. C. T. Lima; C. Riccomini \& N. A. Menezes. 2006. Fishes of the Atlantic Rainforest of Boracéia: testimonies of the Quaternary fault reactivation within a Neoproterozoic tectonic province in Southeastern Brazil. Ichthyological Exploration of Freshwaters, 17: 157-164.

Scaramuzza, C. A. M., L. L. Simões, S. T. Rodrigues, G. M. Accacio, M. Hercowitz, M. R. Rosa, W. Goulart, E. R. Pinagé \& M. S. Soares. 2011. Visão da Biodiversidade da Ecorregião Serra do Mar: domínio biogeográfico Mata Atlântica. Brasília, WWF-Brasil. 167 p.

Severi, W. \& Cordeiro, A. A. M. 1994. Catálogo de peixes da bacia do rio Iguaçu. Curitiba, IAP/GTZ, 118p.

Silveira, L. G. G., F. Langeani, W. J. Graça, C. S. Pavanelli \& P. A. Buckup. 2008. Characidium xanthopterum (Ostariophysi: Characiformes: Crenuchidae): a new species from the Central Brazilian Plateau. Neotropical Ichthyology, 6: 169-174.

Taphorn, D. C. B., C. G. Montaña \& P. A. Buckup. 2006. Characidium longum (Characiformes: Crenuchidae), a new fish from Venezuela. Zootaxa, 1247: 1-12.

Taylor, W. R. \& G. C. Van Dyke. 1985. Revised procedures for staining and clearing small fishes and other vertebrates for bone and cartilage study. Cybium, 9: 107-119.

Travassos, H. 1944. Contribuições ao estudo da família Characidae Gill, 1899 I. Characidium grajahuensis n. sp. Boletim do Museu Nacional do Rio de Janeiro, Nova Série, Zoologia, 30: 1-10.

Travassos, H. 1946. Contribuicão ao estudo da família Characidae Gill, 1893. II. Characidium timbuiensis n. sp. (Classe Actinopterygii--Ordem Ostareophysi). Summa Brasiliensis Biologiae, 1: 1-50.
Travassos, H. 1949a. Notas ictiológicas. I. Characidium lauroi n. sp. (Actinopterygii, Ostariophysi). Revista Brasileira de Biologia, 9: 87-92.

Travassos, H. 1949b. Notas ictiológicas. II. Characidium japuhybensis n. sp. (Actinopterygii, Ostariophysi). Revista Brasileira de Biologia, 9: 229-233.

Travassos, H. 1955a. Sôbre um novo peixe do Estado do Paraná (Actinopterygii-Cypriniformes-Characoidei). Anais da Academia Brasileira de Ciências, 27: 365-371.

Travassos, H. 1955b. Contribuição ao estudo de família Characidae Agassiz, 1844 - VI. Characidium alipioi n. sp. Arquivos do Museu Nacional de Rio de Janeiro, 42: 613-618.

Travassos, H. 1967. Três novas espécies do gênero Characidium Reinhardt, 1866 (Actinopterygii, Characoidei). Papéis Avulsos de Zoologia, 20: 45-53.

Weitzman, S. H. \& R. H. Kanazawa. 1978. The South American fish genus Elachocharax Myers with a description of a new species (Teleostei: Characidae). Proceedings of the Biological Society of Washington, 91: 158-183.

Zanata, A. M. \& P. Camelier. 2015. Two new species of Characidium Reinhardt (Characiformes: Crenuchidae) from Northeastern Brazilian coastal drainages. Neotropical Ichthyology, 13: 487-498.

Zanata, A. M. \& W. M. Ohara. 2015. A new species of Characidium Reinhardt (Ostariophysi: Characiformes: Crenuchidae) from headwaters of rio Pacaás Novos, rio Madeira basin, Rondônia, Brazil. Zootaxa, 4021: 368-376.

Zanata, A. M., L. M. Sarmento-Soares \& R. F. Martins-Pinheiro. 2015. A new species of Characidium Reinhardt (Ostariophysi: Characiformes: Crenuchidae) from coastal rivers in the extreme south of Bahia, Brazil. Zootaxa, 4040: 371-383.

Zarske, A. 1997. Geryichthys sterbai gen. et spec. nov. und Microcharacidium geryi spec. nov.: Beschreibung einer neuen Gattung und zweier neuer Arten von Bodensalmlern aus dem Einzugsgebiet des rio Ucayali in Peru (Teleostei: Ostariophysi: Characiformes: Characidiidae). Zoologische Abhandlungen, Staatliches Museum für Tierkunde in Dresden, 49: 157-172.

Zarske, A. \& J. Géry. 2001. Beschreibung von drei neuen Arten der Gattung Characidium Reinhardt, 1866 aus Bolivien und Paraguay (Teleostei: Characiformes: Characidiidae). Zoologische Abhandlungen, Staatliches Museum für Tierkunde in Dresden, 51: 229-246.

Submitted February 18, 2016 Accepted August 10, 2016 by Francisco Langeani 